\title{
The "U" Technique An Easiest Norplant Removal Procedure *
}

\author{
Untung Praptohardjo ${ }^{* *}$, Susilo Wibowo ${ }^{* \star}$
}

\begin{abstract}
Abstrak
Perkumpulan Keluarga Berencana Indonesia (PKBI) Jawa-Tengah mengkreasi klem susuk dan metoda pelepasan Norplant yang lebih cepat dan sederhana yang disebut teknik " $U$ ". Studi perbandingan pada pelepasan susuk pada 76 pasien dengan susuk yang teraba dan membayang di bawah kulit dilakukan selama bulan Juni 1991 sampai Mei 1992. Secara acak pasien dibagi menjadi 2 kelompok. Kelompok I (38 pasien) dilepas dengan tehnik lama seperti disarankan oleh produsen dan kelompok II (38 pasien) dengan teknik "U". Setelah dilakukan insisi, waktu yang diperlukan untuk melepas seluruh susuk, jumlah susuk yang utuh, serta jumlah insisi yang diperlukan dicatat. Hasil studi menunjukkan, waktu pelepasan susuk dengan teknik "U" (mean=6,8 menit) secara statistik sangat bermakna lebih cepat dari 19,9 menit dengan teknik yang biasa dan jumlah susuk yang utuh lebih banyak dibanding dengan teknik lama. Meskipun jumlah insisi secara statistik tidak berbeda bermakna tetapi perlu dicatat bahwa 5 pasien yang dilepas dengan teknik lama memerlukan 2 insisi sedangkan yang dilepas dengan teknik " $U$ " seluruhnya hanya dengan 1 insisi.
\end{abstract}

\begin{abstract}
The Indonesian Planned Parenthood Association (IPPA) of Central-Java in Semarang, Indonesia has designed the "U" technique using specific implant forceps (modified from vas deferens fixing clamps or hemostatic forceps) as a very simple procedure for implant removal. A comparative study was done on the removal techniques on 76 visible and or palpable implant patients during June 1991 to Mei 1992. Patients were randomly divided into two groups. Group I (38 patients) was allocated for the ordinary technique suggested by the manufacturer and group II (38 patients) for the " $U$ " technique. The time for the complete removal after incision for each technique as well as the number of undamaged silastic tube of implant and numbers of incision were compared. The result of this study revealed that the implant removal time for the " $U$ " technique (mean $=6.8$ minutes) was statistically significant shorter than (19.9 minutes) the ordinary technique and produced significantly greater number of undamaged implant silastic tubes. Five patients with the ordinary technique needed to have 2 incisions and none with the " $U$ " technique.
\end{abstract}

Keywords: New technique of implant removal, Implant forceps, Site of incision

\section{INTRODUCTION}

By the end of 1989 the Norplant ${ }^{\mathrm{R}}$ subdermal implants contraception has been used in clinics and preintroduced in 44 countries. World-wide use of Norplant ${ }^{R}$ contraception is expected to be dramatically increased over the next few years. ${ }^{1}$ As well as many countries, Indonesia began to expand Norplant ${ }^{\mathrm{R}}$ services and regularized them into the Family Planning program. It is important that clinics carrying out Norplant ${ }^{R}$ inser- tions should also be ready to remove the implants anytime upon request by the patients or at the end of the fifth year. The removal of the implants should be performed very gently and will take longer than insertion.' Recently, Darney, Klaise and Walker ${ }^{2}$ developed an alternative method which require fingers and scalpel only and named as "Pop-out" method. Unfortunately the "Pop-out" removal required slightly more time (mean time 20 minutes) than the ordinary technique.

* Presented at the IPPF ESEAO Regional Workshop on Contraceptive Technology and Field Observation on Norplant Programme, Desember 14-18, 1992, Semarang, Indonesia.

** Department of Obstetrics and Gynecology, Faculty of Medicine, Diponegoro University, Semarang, Indonesia.

***Andrology Unit, Department of Biology, Faculty of Medicine, Diponegoro University, Semarang, Indonesia 
After several years of experience with difficulties to remove the implants, the Indonesian Planned Parenthood Association (IPPA) of Central-Java in Semarang, Indonesia, had developed a new technique. This paper will discuss the study and details in developing the new technique on Norplant ${ }^{R}$ removal.

\section{MATERIALS AND METHODS}

The study was conducted from June 1991 to May 1992 at IPPA Central Java Clinic and at Kemlokol village, Central Java, Indonesia. In order to eliminate the bias and error due to the difficulties in finding or locating the unpalpable implants, only patients who had been using Norplant ${ }^{\mathrm{R}}$ for 5 years and having a visible or palpable implants were retained for this study. Seventy six patients participated in this study. They were randomly divided into two groups. Group I (38 patients) was allocated for the ordinary technique suggested by the manufacturer and group II (38 patients) for the " $U$ " technique. The same local anesthesia procedure and patient position were performed to both groups.

Each patient was treated with careful aseptic technique, and the high-level disinfection of instruments by boiling or soaking in a chemical disinfectant were used as recommended.

\section{The conventional ("Ordinary") technique}

The main equipments suggested by Norplant $^{R}$ manufacture are Mosquito forceps, Crile forceps and scalpel. $^{1}$

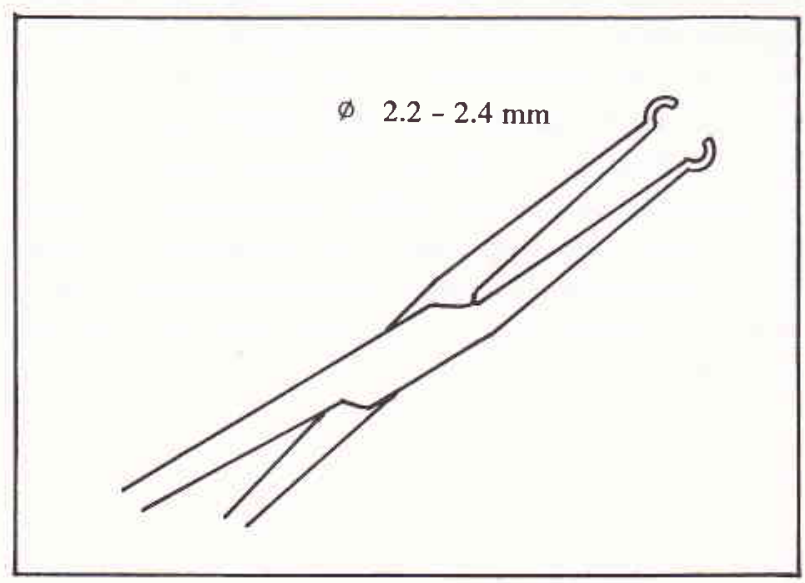

Figure 1a. The implant forceps
The implants were located by palpation and if possible, their positions were marked with a ballpoint pen. After local anesthesia, a $4 \mathrm{~mm}$ transversal incision was made close to the end of implants (below the implants).

The implants were pushed gently toward the incision with left fingers and then each visible implant tip was grasped with mosquito forceps. Open the capsul which covered each implant and remove it using the crile forceps. In most cases we had to remove the implants using the technique for removing inaccessible capsules suggested by the manufacturer and if not successful the patients were asked to return for a second visit."

\section{The "U" technique}

In this particular technique, the following equipments are needed: (1) special forceps (modified from vas defferent-fixing clamps or hemostatic forceps). The tip was bended to form a circular tip with a diameter of approximatelly the same as the implant that is $2.2 \mathrm{~mm}$ - $2.4 \mathrm{~mm}$ and named as "implant forceps" (Fig. 1a). (2) Other forceps (Mosquito or Crile or hemostatic forceps). (3) Scalpel.

The implants were also located by palpation. Whenever possible their positions were marked with a ballpoint pen. The location of incision is different than the ordinary technique. In this technique the site of incision is determined close to the implant number 3 or 4 , approximately $0.5-1 \mathrm{~cm}$ along the implants toward the end of all implants (fig. 1b). After a proper local anestetic procedure, a $4 \mathrm{~mm}$ incision was made longitudinally.

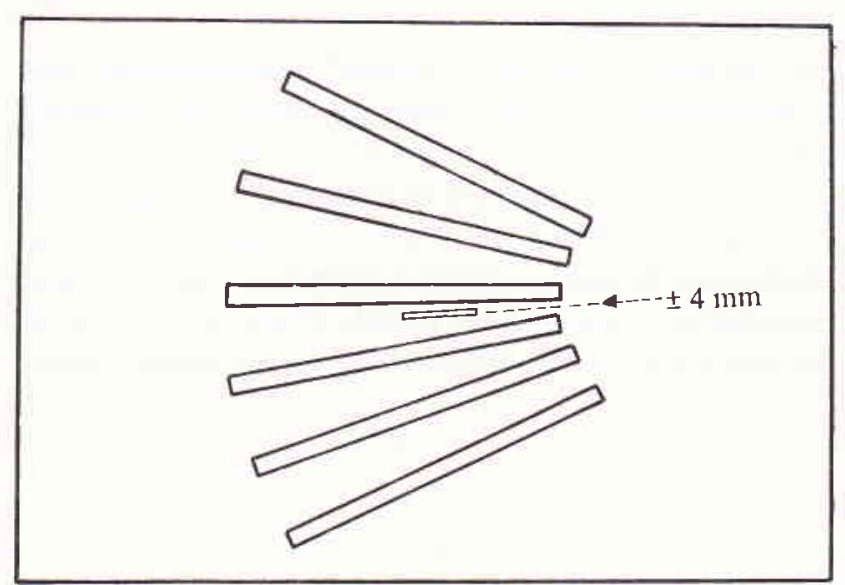

Figure 1 b. Location of incision in the " $U$ " technique 
The implant's rods were grasped using implants forceps and pulled out. Afterwards, the implant forceps handle was turned over $180^{\circ}$ toward patient's shoulder or palm (fig. 2).

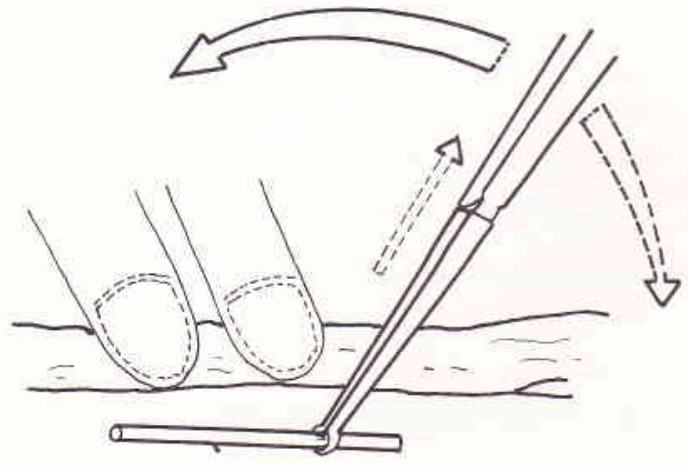

Figure 2. Procedure to grasp the implant in the "U" technique

The soft tissue surrounding the rod of implants were cleaned with gauze. The scalpel could be used to scrape away the soft tissue, then the capsules were opened longitudinally. Using the second forceps the visible part of the implant could be grasped and removed easily.

The time for the proper local anesthetic varied, merely depending on the patient's sensitivity. Therefore the time of removal was assessed from the time after incision to the time of complete removal. The number of undamaged / unbroken implants as well as the number of incisions were also counted and compared.

\section{RESULTS}

Sample data collected from this study showed that the removal time was in normal distribution, but the number of undamaged / unbroken silastic tube of implant as well as the number of incisions were not in normal distribution. Therefore the pooled $\mathrm{T}$ test and MannWhitney test were used.

The removal of implants usually take longer time than insertion. Using the ordinary technique, the removal of visible and or palpable implants took 6 to 35 minutes and the mean time was 19.86 minuts (see table 1). The number of incisions were not significantly different, 5 patients needed 2 incisions in order to remove complete implants with the ordinary technique and none with the " $\mathrm{U}$ " technique.

Table 1. The mean removal time (minutes), the number of undamage/ unbroken implants, the number of incision in the " $U$ " (38 patients) and Ordinary technique ( 38 patients)

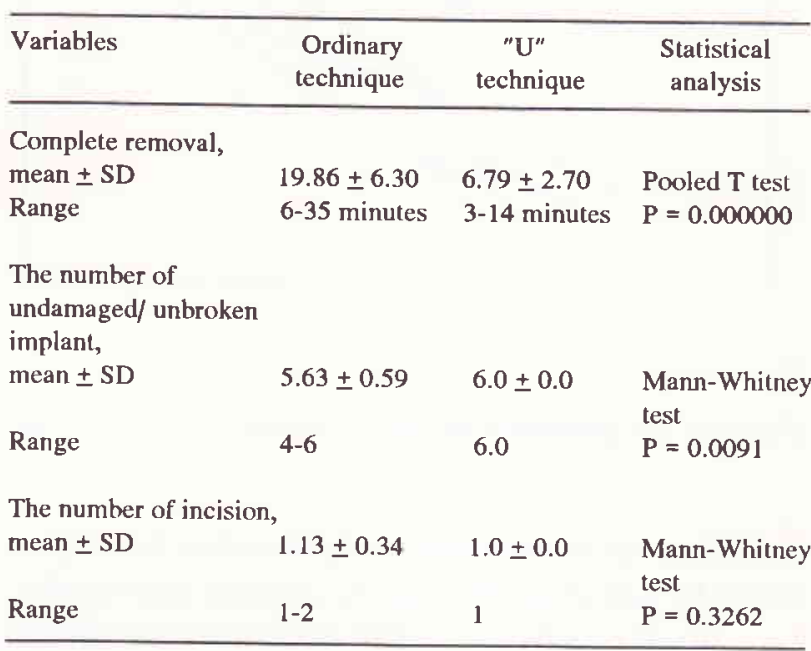

\section{DISCUSSION}

The removal time using the ordinary technique in this study seem close to the removal time of "Pop-Out" method (mean time 20 minutes) developed by Darney, Klaise and Walker. ${ }^{2}$ During the removal procedures the operator often faced the problems that some of the silastic tube-end were inaccessible (more than $1 \mathrm{~cm}$ from the incision site). In this particular condition, it was really hard to push with the left fingers or grasp and pull the implant using Mosquito forceps toward the incision. Some of these problems seem likely to be solved if the implants were grasped using implants forceps. Therefore the removal time using the " $U$ " technique was much shorter i.e. the mean time was 6.79 minutes (table 1 ).

It is well known that the cylindrical capsules of the silastic tube are easy to slip out under open angle (mouth) of mosquito forceps (fig. 3a).

Under these circumtances the operator should try to grasp tightly and perhaps also to push the implants harder in order to pull it out. If the operator grasps too tight, the silastic tube might be broken or damaged during the effort. After several unsuccesfull efforts the operator might decide to make an other incision close to the remainder implants. This problem did not happen if we used the implant forceps. The implant forceps would hold the cylindrical capsules of implants perfectly (Fig. 3b). The circular tips of the implant forceps 

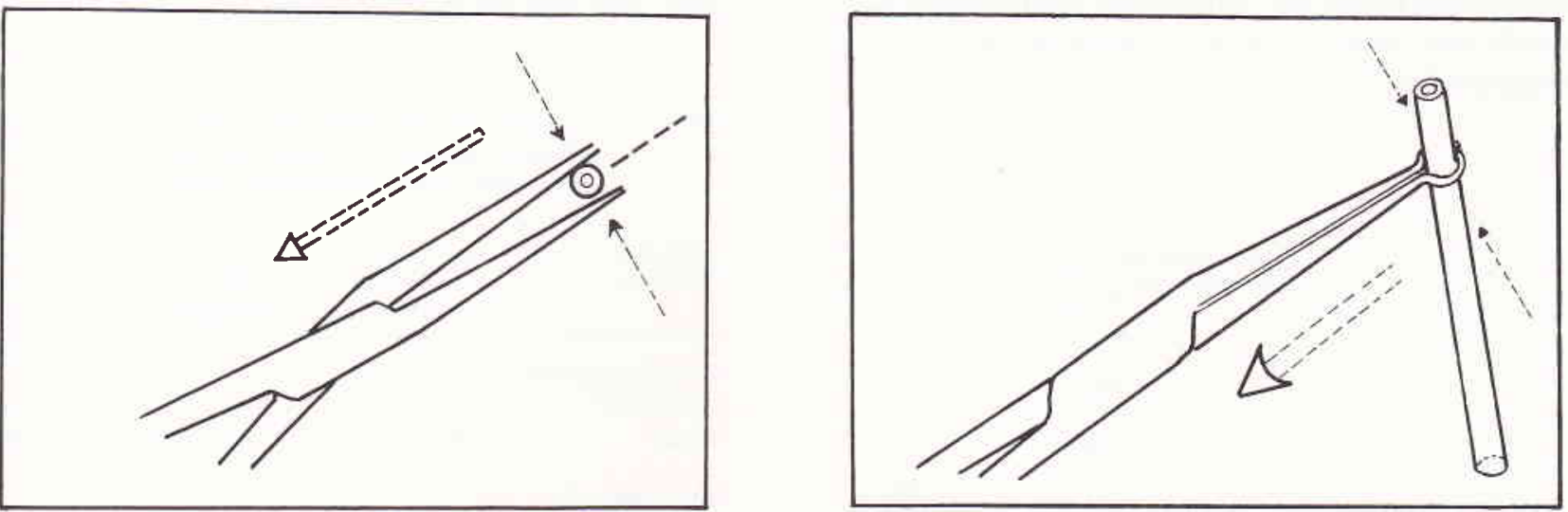

Figure 3. The position of the silastic tube of implant in the tip of inosquito forceps (3a) and implant forceps ( $3 b$ )

would act as an excellent hook, therefore the implant could be pulled out through the incision more easily.

In our experiences, some of the tissue or capsules at the tip of implants were thicker than at the surrounding rod of implants. Therefore, the operator might spend more time to clean, to scrape away the soft tissue and to open the capsules compared to those who grasped the rod of implants using implant forceps.

The location of incision also played an important role in implant removal. Firstly, in the ordinary technique the operator would grasp the tip of the implants and in the new technique the operator would grasp the rod as we mentioned above. Secondly, if the distances of inter-lower-end of implants are more than $1 \mathrm{~cm}$ and the operator made an incision $0.2-0.5 \mathrm{~cm}$ close to the end of most implants (below the implant), the distance of the furthest implant-end to the incision opening might be more than $1 \mathrm{~cm}$. In this condition, it was very difficult to remove the remainder implant. It would take longer because the implants capsules were slippery or the operator had to make another incision. When the new technique was adapted, the distances of each implant rod to the incision might be less than 1 $\mathrm{cm}$. Even if the distance was more than $1 \mathrm{~cm}$ the rod of the implants was easier to grasp than the tip of implants. Nowadays, the operators at IPPA Central Java are more familiar with the " $U$ " technique and experienced operators were able to remove the visible implants as quick as inserting it. This new technique was then called "UNTUNG" technique or " $U$ " technique after the name of the founder.

The " $U$ " technique seems likely to be more convenient and preferable for both the operators and the patients.

\section{Acknowledgements}

We gratefully acknowledge Dr. Endang Ambarwati, Mrs. Didit Budiningsih and Mr. Abadi for their help in data collecting. The authors also would like to thank Dr. Fatimah Moeis, MSc, for her generous help in preparing this manuscript.

\section{REFERENCES}

1. Norplant ${ }^{\mathrm{R}}$, Contraceptive implants. Instruction for insertion/ removal. Leiras Oy, Turku, Finland.

2. Darney PD, Klaise CM and Walker DM. The 'pop-out' method of Norplant removal. Advances in Contraception. (Abstracts Eighth Annual Meeting, Barcelona, Spain; 1992; $8(3): 188-9$

3. Tietjen L, W. Cornain, McIntosh N. Infection Prevention for Family Planning Service Programs. A Problem-Solving References Manual, Essential Medical Information Systems, Durant, USA. 1992, 152-67. 